v. $13, n .4$

Vitória-ES, Jul.-Aug. 2016

p. 1 - 23 ISSN 1808-2386 DOI: http://dx.doi.org/10.15728/bbr.2016.13.4.1

\title{
What Must be Considered when to Perform Consumption Analytics with Facebook Posts?
}

\author{
Nelson Siqueira Rangel Netto \\ Federal University of Espírito Santo - UFES \\ Teresa Cristina Janes Carneiro ${ }^{\Omega}$ \\ Federal University of Espírito Santo - UFES \\ Marcos Paulo Valadares de Oliveira ${ }^{¥}$ \\ Federal University of Espírito Santo - UFES \\ Rogério Antônio Monteiro ${ }^{ \pm}$ \\ Federal University of Espírito Santo - UFES
}

\begin{abstract}
This paper aims to discuss and present empirical evidences about whether online recommendations posted on Facebook can be related with consumption intention of its users. Moreover, the perceived reputation of the source of the information, the perceived value of the recommended product, and the perceived risk associated with the product were also considered as possible mediators of this relationship. In this sense, the structural relationship among the variables was assessed through SEM - Structural Equation Modeling. To conduct the study, the Facebook contacts of the author himself were screened using the Snow Ball sampling technique. A total of 402 valid cases were obtained. Among the mediating variables, the one that exerted the least total effect in the relationship was the perceived risk associated with the recommended product. The variable for the consumption intention had a value for $\mathrm{R}^{2}$ of $47 \%$, which indicates that the model significantly contributes to the explanation of the influence of the tested factors in the consumption intention of Facebook users. This finding indicates that organizations should invest in monitoring these behaviors and in proactive measures to stimulate consumption.
\end{abstract}

Keywords: Facebook. Social networks. Internet. Consumption. Electronic word of mouth.

Received on 01/29/2015; Reviewed on 04/07/2015;Accepted on 05/07/2015; Divulgued on 07/04/2016.

*Author for correspondence:

†. Master in Administration.
Link: Federal University of
Espírito Santo - UFES
Address: Avenue Fernando
Ferrari, 514, Goiabeiras, Vitória -
ES - Brazil. Cep. 29075-910.
E-mail: rangeln@ terra.com.br

E-mail: rangeln@terra.com.br

$\Omega$ Doctor in
Administration.
Link: Federal University of
Espírito Santo - UFES.
Address: Avenue Fernando
Ferrari, 514, Goiabeiras,
Vitória-ES - Brazil. Cep.
29075-910.
E-mail:
teresa.carneiro@ufes.br

$¥$ Doctor in Administration. Link: Federal University of Espírito Santo - UFES. Address: Avenue Fernando Ferrari, 514, Goiabeiras, Vitória - ES - Brazil. Cep. 29075-910.

E-mail:

marcos.p.oliveira@ufes.br \pm Doctor in PhD in
communication and
semiotics
Link: Federal University
of Espírito Santo -
UFES.
Address: Avenue
Fernando Ferrari, 514,
Goiabeiras, Vitória - ES -
Brazil. Cep. 29075-910.
E-mail:
rogerio.monteiro@ufes.br 


\section{INTRODUCTION}

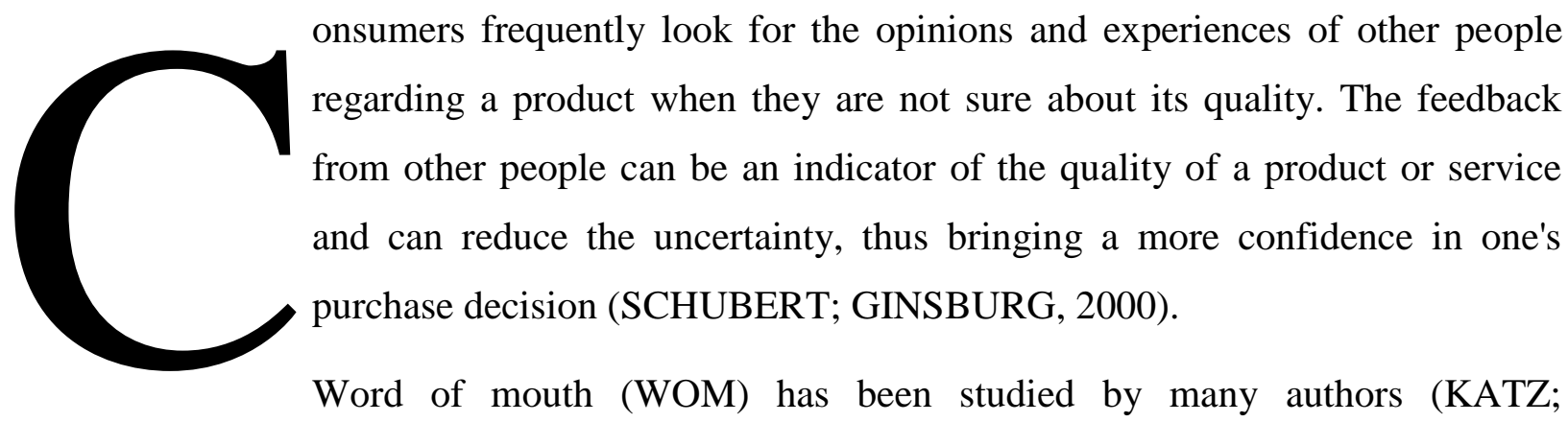

LAZARSFELD，1955; BROOKS，1957; ARNDT，1967; RICHINS，1983; REINGEN, 1987; TAX; BROWN; CHANDRASHEKARAN, 1998; BUTTLE, 1998; HARRISON-WALKER, 2001; GOLDENBERG; LIBAI; MULLER, 2001; YANG et al., 2012; VÁZQUEZ-CASIELLES; SUÁREZ-ÁLVAREZ; DEL RÍO-LANZA, 2013) and has been shown to be important in client's purchase decision (BELK, 1971; RICHINS; ROOTSHAFFER, 1988; BONE, 1992; DUHAN et al., 1997; BANSAL; VOYER, 2000; BROWN et al., 2005; LÓPEZ; SICILIA, 2013). Its importance was justified by Silverman (1997, p. 32) due to the proximity to the moment at which the purchase decision is made: "word of mouth has been regarded as the nearest cause for purchase - the most immediate thing that happens before the purchase. In other words, it acts as the trigger for the purchase."

According to Berger and Iyengar (2013), written word of mouth influences the consumer's purchase decision with more intensity than oral communication. Additionally, according to Feick and Price (1987), interpersonal sources of information are considered to have greater credibility than non-personal sources, which indicates that information obtained from interpersonal sources influences the decision-making process related to consumption, as has been acknowledged in previous marketing literature on consumer behavior (ARDNT, 1967; IKEDA, 1999; SCHIFFMAN; KANUK, 2000). Schiffman and Kanuk (2000) state that, when people maintain contact with other people, particularly family, friends, and individuals they admire, this contact influences their lives.

With the advent of new media, there are now more opportunities to exchange information about consumer goods not only due to the ease of interaction between members of a social network but also due to the ease of making contacts with new friends online (HUNG; LI, 2007). Online comments are a type of word of mouth that provides information on a product from the client's point of view (LEE; PARK; HAN, 2008). There are people who actively recommend and share opinions and experiences to help other consumers to judge the 
quality of a product or service (PARK; LEE; HAN, 2007; KIM; HOLLAND; HAN, 2013; KIM, 2014).

Traditional word of mouth has evolved into electronic word of mouth (eWOM), which is also known as online recommendation (CHATTERJEE, 2001; SENECAL; NANTEL, 2004) because it takes place in a virtual environment. Social networking sites, such as Facebook, are important for electronic word of mouth because these are the means through which consumers freely share their experiences and opinions on products and services, rapidly spreading their opinions through networks of friends, personal contacts, and other acquaintances (RAACKE; RAACKE, 2008). The relevance of electronic word of mouth to marketing strategies has been increasing due to its high level of transparency and the wide reach of social networking sites.

With greater visibility, social networking sites are influencing a continuously increasing number of people (CHEUNG; LEE; RABJONH, 2008). Therefore, the comprehension of this phenomenon becomes a competitive factor for organizations because it creates the need to intensify and qualify their involvement in the network to ultimately know what is being recommended and decide whether to promote "spontaneous" recommendations.

Facebook, which is one of the most popular social networking sites, has already reached more than one billion users worldwide. This represents more than $14.28 \%$ of the world's population. This growth has sparked the interest of organizations to establish a new type of relationship with clients, e.g., to seek new market niches. Companies are increasingly creating profiles on these networks to obtain a variety of goals, such as the recruitment of individuals, sales, customer relations, and public relations in general.

As mentioned before, although there are studies on the impact of traditional word of mouth on consumer behavior, just more recently the electronic word of mouth has being considered (CHEUNG; LEE; RABJONH, 2008; DUANA; BIN; WHINSTON, 2008; GUPTA; HARRIS, 2010; CHEUNG; THADANI, 2012; BERGER; IYENGAR, 2013; SANDES; URDAN, 2013; CANTALLOPS; SALVI, 2014).

Recommendations of products and services made by users of social networks are perceived according to various factors, including the reputation (RECUERO, 2009; KU; WEI; HSIAO, 2012; AARIKKA-STENROOS; MAKKONEN, 2014; CAI et al., 2014), the perceived value of the product or service (SWENNEY; SOUTAR, 2001; SANCHEZ; INIESTA, 2007; KIM; HOLLAND; HAN, 2013; LIN; KUO, 2013; KIM, 2014), and the 
perceived risk of the product or service (CUNNINGHAM, 1967; BETTMAN, 1973; WOOD; SHEER, 1996; HA, 2002; SUN, 2014).

Reputation is a perception of one actor by the others that directly implies that information is made available in the network about who we are and what we think that helps other people construct their impressions of us. An individual's reputation will always be the result of the impressions that others have of him/her - impressions that will always be the result of interpretation and are thus not always rational or objective. The notion of reputation is closely related to that of authority. Authority can be considered the influence power of an actor over his audience. Similarly to reputation, authority originates only from an intersubjective relationship between the emitter and the receiver, in which the former becomes influential only when the latter acknowledges the value of the information being forwarded. The intelligibility of a message's content depends on the acknowledgment of the author's authority by the reader (RECUERO, 2009).

According to Sheth, Newman and Gross (1991), the perceived value of a consumer good, product, or service is the perceived usefulness as the result of its ability to perform its functional, utilitarian, and physical aspects. The authors consider that there is a social motivation for consumption, namely, the perceived social value or usefulness of a given product or service, as a result of its participation in a social group.

Schiffman and Kanuk (2000) state that consumers seek information about a product through word of mouth from friends, family, and other people whose opinions they value. Consumers spend more time thinking about their choices and seek more information about product alternatives when they attach a high level of risk to it. The more information the consumer has about the product, the more predictable are the consequences, and thus the lower is the perceived risk.

The present article aims to analyze the effects of electronic word of mouth over consumption intention. The interest and motivation of this study arose from the difficulty associated with the use of social networks by organizations as part of their marketing strategies considering the possible consequences to the organizational image and performance.

Thus, the goal is to understand whether online recommendations affect the consumption intention of social network and whether this association is mediated by the perceived 
reputation of the source of information, the perceived value of the recommended product or service, and/or the perceived risk.

\section{RESEARCH MODEL CONCEPTUALIZATION}

In order to develop the research model to be used for this study, that aims to evaluate the mediation rule of three distinct constructs over the relationship between the constructs of online recommendation and consumption intention, this section presents a brief conceptualization about the model's constructs and its relationships. Moreover, it is important to point out that according to Solomon (2002), consumption is the study of the processes that take place when individuals or groups select, purchase, use, or dispose of products, services, ideas, or experiences to satisfy their desires and needs. In the present study, the concept of consumption intention rather than that of purchase intention will be addressed with the aim of not characterizing an exclusively financial transaction and thus embracing a larger number of consumption possibilities.

\subsection{CONSUMPTION INTENTION}

Schiffman and Kanuk (2000) note the social-cultural input as a factor that influences the consumer's decision-making process. These authors view this input as based on external influences, which serve as sources of information for a determined product and influence the consumer in terms of values, attitudes, and behaviors related to the product or service. The social-cultural input consists of a wide array of non-commercial influences. In this sense, intention precedes real behavior, i.e., it is the predisposition to carry out a given behavior (FISHBEIN; AJZEN, 1975).

\subsection{ONLINE RECOMMENDATION}

With the advent of the Internet, social groups have gained an electronic tool that allows people to maintain their relationships active, even if physically distant. Thus, consumers have started interacting with each other rapidly and conveniently, which has resulted in the establishment of the phenomenon known as online interpersonal influence or electronic word of mouth (GOLDENBERG; LIBAI; MULLER, 2001; BICKART; SCHINDLER, 2001; HUNG; LI, 2007; RAACKE; RAACKE, 2008). To Henning-Thurau et al. (2004, p. 39), electronic word of mouth is "any positive or negative statement made by the potential, current, or former client of a product or company that is made available to many people and institutions through the Internet." Electronic word of mouth can take place in different online channels, such as e-mails, discussion forums, instant messages, homepages, blogs, product sites, online communities, newsgroups, chat rooms, and social networking sites. 


\subsection{PERCEIVED VALUE}

Zeithaml (1988) contributed to the development of the concept of perceived value exploring the relationship between consumer perception, price, quality, and value. The author's studies reveal that "perceived value" is used in different ways and presents a variety of attributes, which may signify "value”. In Zeithaml's study (1988), several definitions for "value" appeared: (1) value is low price, (2) value is anything one desires from a product, (3) value is the quality one gets for the price one pays, and (4) value is the quality one gets for what is conceded.

\subsection{PERCEIVED REPUTATION}

One of the most important values one builds in social networks is reputation (RECUERO, 2009; HUNT, 2010; KU; WEI; HSIAO, 2012; AARIKKA-STENROOS; MAKKONEN, 2014; CAI et al., 2014). According to Buskens (1998), reputation is related to the information received by social actors regarding the behavior of others and the use of this information to decide how to behave.

According to Recuero (2009), reputation is the perception of an individual by the other actors; the concept of reputation directly implies that there is information about who we are and what we think, which assists others in building their impression of us. According to Goffman (1975), one could say that a person's reputation is a consequence of all impressions voiced about this person. Reputation, therefore, can be influenced by actions and also depends on the constructs that others make upon these actions.

\subsection{PERCEIVED RISK}

Consumers have to constantly make decisions about which products or services to consume. According to Schiffman and Kanuk (2000), because the results of such decisions are often uncertain, the consumer perceives some degree of risk when making a purchase decision. Perceived risk is defined as the uncertainty met by consumers when they cannot predict the consequences of their consumption decisions.

Although the risk may be real, consumers are influenced by the risks they perceive. The real risk, which is also known as objective risk, is what actually exists, whereas the perceived risk, which is also called subjective risk, is what an individual perceives in a given situation (CUNNINGHAM, 1967). Consumers are influenced by the risks they perceive, which are independent of the existence of real risk (SCHIFFMAN; KANUK, 2000). 
Procter and Richards (2002) hypothesize that word of mouth communication extenuates the perceived risk because "consumers do not have to take on the risks of trying out new products when people in whom they believe can share that risk." In an effort to reduce risk, consumers often obtain information related to the product or service in question through word of mouth communication (BANSAL; VOYER, 2000).

Based on the theoretical arguments presented, hypotheses along a theoretical model for the study are presented in Figure 1.

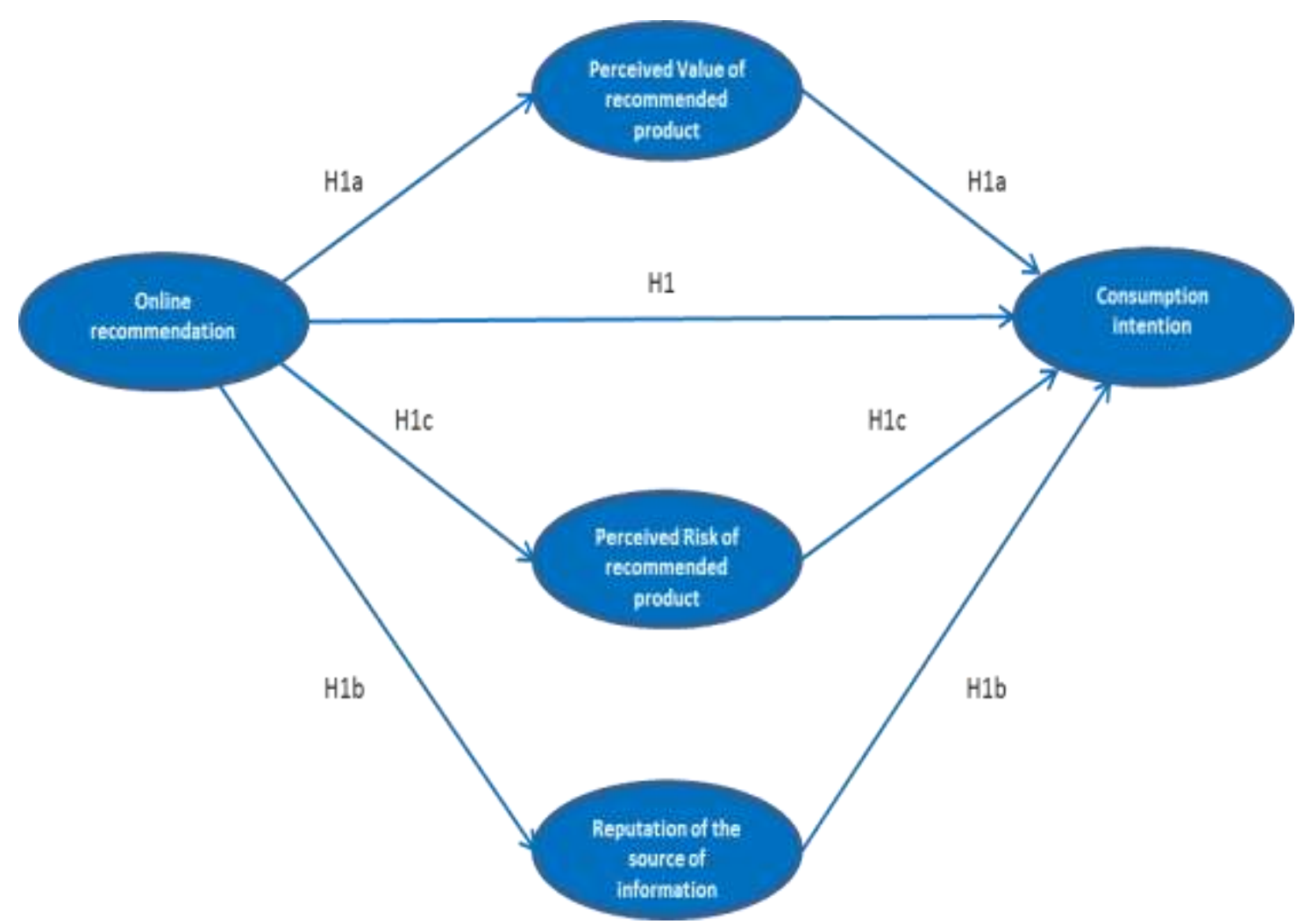

Figure 1 - Theoretical model for the study Source: Elaborated by authors.

$\mathbf{H}_{1:}$ Online recommendations affect consumption intention.

$\mathbf{H}_{1 \mathbf{a}}$ The impact of online recommendations over consumption intention is mediated by the perceived value of the recommended product.

$\mathbf{H}_{1 \mathbf{b}}$ : The impact of online recommendations over consumption intention is mediated by the perceived reputation of the source of the information.

$\mathbf{H}_{1 \mathbf{1}}$ : The impact of online recommendations over the consumption intention is mediated by the perceived risk of the recommended product. 


\section{VARIABLES OPERATIONALIZATION AND DATA COLLECTION}

The data were collected using the Snow Ball sampling technique. This approach requires the allocation of an initial group of interviewees with certain traits. These individuals, in addition to being part of study, are used as informants in the identification of other possible individuals with similar traits who may be included in the study (MALHOTRA, 1999). This process is used successively to identify the largest possible number of individuals who may contribute to the investigation

An electronic questionnaire in the form of a survey was used (Appendix 1). This questionnaire, which used a five-point Likert scale, was made available on the Internet in a link posted on the first author's Facebook. Facebook was chosen because it is one of the most popular social networking sites with more than one billion users worldwide. By using Facebook, consumers can freely share their experiences and opinions about products and services. The information supplied in profiles is semi-public, visible to all users who are given the right to view it. Even if the main goal of the information in profiles is not to recommend something, it may have a recommendation-type effect on the ones who read it.

When trying to comprehend society as an interconnected group of people, researchers encounter limits. According to Recuero (2009), as the social network study begins, it includes a worldwide range of people, and that's why the division is necessary, to observe the network as a whole, or as a specific limited portion. The specific limited portion network approach begins from a particular knot, and from these connections the network is sketched, thus this approach analyses a group of defined knots from one specific actor. This specific limited portion is focused in one individual and its network relationships, and for that reason this research focuses on the network of the author of this paper.

Recuero (2009) highlights that, when developing social network study, one should define the type of network: emerging network or affiliated network. Emerging networks are created from the interactions among social actors whose connections happen through exchange of social interaction and through conversations utilizing computers. Affiliated networks come from the stagnant connections among actors of reactive interactions in the network. These are networks which interactions are forged through association mechanisms or affiliation from social network websites such as the acquaintance list on Facebook which does not indicate a reactive interaction with social effects - once an individual is added, he remains there regardless of interaction that will keep him within the social circle. 
Using a link posted on the first author's Facebook, a total of 405 completed surveys were gathered. After data preparation aiming to detect outliers and missing data, 402 of these were deemed valid. The demographics of the respondents were the following: $52 \%$ women and $49 \%$ men; $46 \%$ married, $46 \%$ single, and 7\% divorced; $35 \%$ with a college degree and $54 \%$ with a post-graduation degree; $26 \%$ between the ages of 31 and 35 years, $22 \%$ between the ages of 26 and 30 years, and $18 \%$ between the ages of 18 and 25 years.

In order to access the hypothetical model purposed for this study, PLS-SEM was used. PLS-SEM is evolving as a statistical modeling technique that focuses on explaining the variance in the dependent variables when examining the model. This method is considered as a preferred method when the research objective is theory development and prediction of the constructs (HAIR JUNIOR et al., 2014). For the aims of the research, both measurement model and structural model were then accessed and results are presented in the following sections.

\section{MEASUREMENT MODEL}

PLS-SEM was used to evaluate the measurement model for the following formative constructs: online recommendation (REC), perceived value of the recommended product (VP), perceived reputation of the source of information (REP), and perceived risk in the recommended product (RIP). Using this information, the correlations between each pair of construct indicators were obtained, and the multicollinearity of these was assessed. After performing all of the pair-wise tests between each indicator and the remaining indicators for the same construct, it was observed that only the Q2G indicator had a VIF between 5.5 and 5.7, which is higher than 5.3 with respect to variables Q2A, Q2B, Q2C, Q2D, Q2E, and Q2I. This result could be considered high collinearity. However, the criterion adopted in this study considers VIF values above 5.3, as recommended by Hair et al. (2009), to represent high collinearity. Therefore, the indicator Q2G was excluded from the model.

Using the bootstrapping function, it was detected that some indicators do not have significance considering its linkage with its respective constructs at the 5\% level, i.e., some indicators displayed t-values below 1.96; these were thus excluded from the model. An exception was Q2F, which had a value of 1.746, which is less than 1.96 and higher than 1.65; because its theoretical relevance in spite of representing a significance level of $10 \%$, this variable was maintained in the model. The following criterion for exclusion was adopted. Those indicators with the smallest $t$-value were excluded one at a time. Ten bootstrapping runs were conducted because this was minimum number of runs required to exhaust the 
possibilities of exclusion. The excluded indicators were Q4B $(t=.197)$, Q4E $(t=.205), \mathrm{Q} 3 \mathrm{C}$ $(t=.516), \mathrm{Q} 4 \mathrm{D}(t=.614), \mathrm{Q} 4 \mathrm{C}(t=.604), \mathrm{Q} 3 \mathrm{~F}(t=.619), \mathrm{Q} 2 \mathrm{I}(t=.793), \mathrm{Q} 2 \mathrm{~A}(t=.631), \mathrm{Q} 3 \mathrm{E}$ $(t=1.001)$, and Q2D $(t=.907)$.

After completing the evaluation of the measurement model, the IC construct (consumption intention), which is the only reflexive construct in the model, met the convergent analysis criteria shown in Tables 1 and 2.

Table 1 - PLS Algorithm

\begin{tabular}{l|c|c|c|c|c|c}
\hline PLS Algorithm & Ave. & $\begin{array}{c}\text { Composite } \\
\text { reliability }\end{array}$ & $\mathrm{R}^{2}$ & $\begin{array}{c}\text { Cronbach's } \\
\text { Alpha }\end{array}$ & Communality & Redundancy \\
\hline IC & 0.752 & 0.924 & 0.47 & 0.889 & 0.752 & 0.199 \\
\hline
\end{tabular}

Source: Elaborated by authors.

Table 2 - PLS Algorithm

\begin{tabular}{l|c|c|c}
\hline PLS algorithm & $\mathrm{R}^{2}$ & Communality & Redundancy \\
\hline REC & & 0.611 & \\
\hline REP & 0.228 & 0.466 & 0.109 \\
\hline RIP & 0.082 & 0.777 & 0.064 \\
\hline VP & 0.239 & 0.521 & 0.124 \\
\hline
\end{tabular}

Source: Elaborated by authors.

According to Hair Junior et al. (2009), at least 200 samples would be required to obtain acceptable communalities within the range of .45 to .55 . To obtain values less than .45 , the authors suggest a minimum of 300 samples. In the present study, which included data from 402 respondents, the minimum requirement of .45 was maintained as a criterion. As observed in Table 2, the smallest communality had a value of .466 .

Table 3 - IC Factor Loadings

\begin{tabular}{l|c|l}
\hline External Loading & Loading & Action \\
\hline Q5A <- IC & 0.793 & Keep \\
\hline Q5B <- IC & 0.874 & Keep \\
\hline Q5C <- IC & 0.905 & Keep \\
\hline Q5D <- IC & 0.892 & Keep \\
\hline
\end{tabular}

Source: Elaborated by authors.

\section{ANALYSIS OF THE STRUCTURAL MODEL}

After the measurement model was adjusted, the structural model was analyzed resulting in a path coefficient between Online Recommendation and Consumption Intention of 0.579 and $\mathrm{R}^{2}$ of 0.336 . By taking the bootstrapping function to assess the significance level of the 
path coefficients through Student's t-test (Table 4), the ratios of all of the path coefficients were found to be higher than 2.57, which is sufficient for them to be deemed significant considering a reference p-value of .05 .

Table 4 - Bootstrapping Path Coefficients

\begin{tabular}{l|c}
\hline $\begin{array}{l}\text { Bootstrapping } \\
\text { Path Coefficients }\end{array}$ & t-statistic \\
\hline REC -> IC & 6.428 \\
\hline REC -> REP & 12.608 \\
\hline REC -> RIP & 5.588 \\
\hline REC -> VP & 11.251 \\
\hline REP -> IC & 3.560 \\
\hline RIP -> IC & 2.646 \\
\hline VP -> IC & 5.618 \\
\hline Source: Elaborated by authors.
\end{tabular}

To complete the evaluation of the model, a goodness-of-fit test was performed. The value resulting from this test was .542 , which indicates that the model proposed in this study is adjusted and validated. Another important result was the determination coefficient $\left(\mathrm{R}^{2}\right)$, which had a value of .47. This value represents the percentage to which the model contributed to the explanation of the variable IC.

\subsection{ANALYSIS OF MEDIATION}

In order to test de mediation effect, initially it was evaluated the direct relationship REC->IC which presented a path coefficient of .579 and a value of $\mathrm{R}^{2}$ of .336 . The relationship's significance was tested by applying T-student's test through bootstrapping, resulting $(\mathrm{t}=16.422$, which is higher than 2.57) in a high significance. After testing the direct relationship REC->IC, the results were compared with the full model previously tested, with the mediating variables VP, RIP, and REP included. The result showed that the beta coefficient of the direct relationship REC->IC improved from .317 to .579 without the mediating variables. This considerable drop of $44.9 \%$ was verified, although all of the relationships were proven significant at a $1 \%$ level. In addition, when comparing the determination coefficient $\left(\mathrm{R}^{2}\right)$ of variable IC in the direct relationship $\mathrm{REC}->\mathrm{IC}$, it decreased from .47 to .336 to with the exclusion of the mediating variables.

Additionally, we also evaluated the full model with the exclusion of the REC->IC relationship by maintaining the variables that mediate these two variables, as shown in Figure 2. 


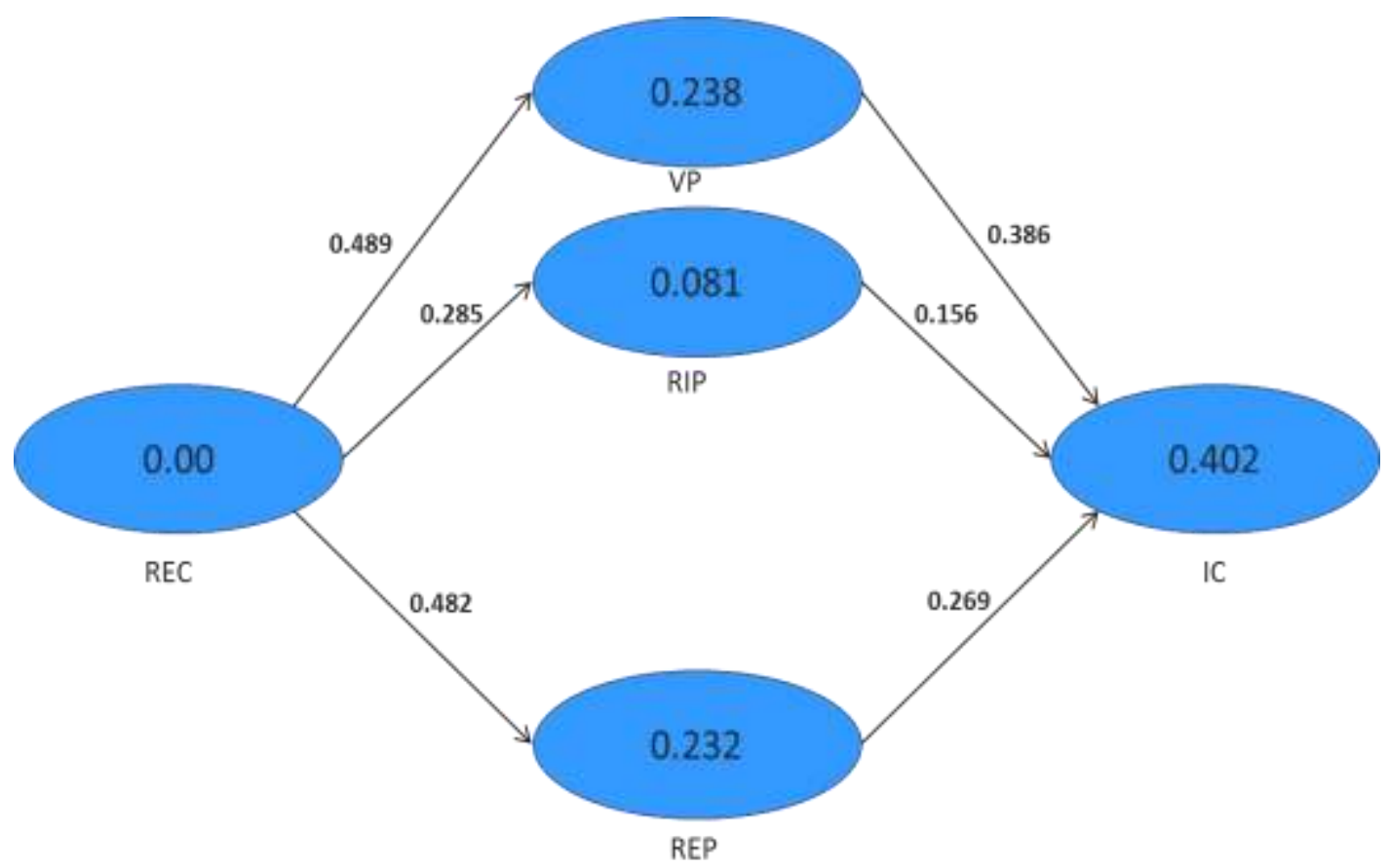

Figure 2 - Results of PLS algorithm using only the mediating variables Source: Elaborated by authors.

The test in which the REC->IC relationship was excluded revealed that the relationships remained significant and that the $\mathrm{R}^{2}$ for variable IC increases from .336 to .402 , which represents a 19\% increase. This result indicates that the impact on the IC construct is greater when only the mediating variables are present compared with when only the direct relationship REC->IC is present. Therefore, the model exhibits partial mediation by the variables VP, RIP, and REP (HAIR JUNIOR et al., 2009).

In another test, the direct and indirect effects between the relationships on the variable IC were computed.

Table 5 - Computation of Indirect and Total Effects on Variable IC

\begin{tabular}{|c|c|c|c|c|}
\hline \multicolumn{3}{|c|}{$\begin{array}{c}\text { INDIRECT EFFECT } \\
\text { (Coefficients are multiplied) }\end{array}$} & $\begin{array}{c}\text { DIRECT EFFECT } \\
\text { REC->IC }\end{array}$ & $\begin{array}{c}\text { TOTAL EFFECT } \\
\text { (Indirect effect }+ \text { direct effect) }\end{array}$ \\
\hline REC->VP & VP->IC & \multirow[b]{2}{*}{0.1393} & \multirow{2}{*}{0.317} & \multirow{2}{*}{0.456} \\
\hline 0.489 & 0.285 & & & \\
\hline REC->RIP & RIP->IC & \multirow[b]{2}{*}{0.0324} & \multirow{2}{*}{0.317} & \multirow{2}{*}{0.349} \\
\hline 0.287 & 0.113 & & & \\
\hline REC->REP & REP->IC & \multirow[b]{2}{*}{0.0869} & \multirow{2}{*}{0.317} & \multirow{2}{*}{0.404} \\
\hline 0.478 & 0.182 & & & \\
\hline
\end{tabular}

Source: Elaborated by authors.

According to Hair Junior et al. (2009), indirect effects with values less than .08 are seldom of interest and hardly ever contribute something substantial to the conclusions. This implies that the relationship REC->RIP->IC might be irrelevant with an indirect effect of 
.0324 , but it was decided to keep it in the model because of its significance level with a risk of less than $1 \%$. The use of the PLS algorithm after the exclusion of the RIP construct resulted in a small decrease of $2.7 \%$ in the value of $\mathrm{R}^{2}$ for variable IC - from .47 to .457 . This result corroborates the claim made by Hair Junior et al. (2009) that indirect effects with values of less than .08 do not substantially contribute to the conclusions.

In the absence of the variable RIP, the model exhibits very small variations, but because the model also exhibits a significant relationship at the $1 \%$ level for this variable, it was deemed important to keep it in the model.

The mediating variable with the greatest total effect on the relationship between online recommendation and consumption intention was the perceived value of the product (45\%), and this was followed closely by the variable source reputation (40\%). To marketing managers, the perceived value is a variable that is hard to manage due to its subjective nature, which is highly dependent on the consumer.

Table 6 shows the final results of the tests of the hypothesis analyzed in this study. All of the hypotheses were sustained, and the model was found to be partially mediated by the variables VP, REP, and RIP.

Table 6 - Final Evaluation of the Hypotheses

\begin{tabular}{|l|l|l|}
\hline & Hypotheses & Result \\
\hline $\mathrm{H}_{1}$ & Online recommendations affect the consumption intention. & Supported \\
\hline $\mathrm{H}_{1 \mathrm{a}}$ & $\begin{array}{l}\text { The perceived value of the recommended product mediates the impact of online } \\
\text { recommendations on the consumption intention. }\end{array}$ & $\begin{array}{l}\text { Supported - Partial } \\
\text { Mediation }\end{array}$ \\
\hline $\mathrm{H}_{1 \mathrm{~b}}$ & $\begin{array}{l}\text { The perceived reputation of the source of the information mediates the impact of } \\
\text { online recommendations on the consumption intention. }\end{array}$ & $\begin{array}{l}\text { Supported - Partial } \\
\text { Mediation }\end{array}$ \\
\hline $\mathrm{H}_{1 \mathrm{c}}$ & $\begin{array}{l}\text { The perceived risk of the recommended product mediates the impact of online } \\
\text { recommendations on the consumption intention. }\end{array}$ & $\begin{array}{l}\text { Supported - Partial } \\
\text { Mediation }\end{array}$ \\
\hline
\end{tabular}

Source: Elaborated by authors.

\section{DISCUSSION OF THE RESULTS AND FINAL REMARKS}

The results of this study shows that online recommendations made on Facebook affect the consumption intention of its users and this relationship is significantly mediated by the following variables: perceived reputation of source, product's perceived value, and perceived risk. The variable perceived risk, despite having little impact on the model, was shown to be significant.

The first hypothesis assumed that online recommendations influence the consumption intention with a $\mathrm{R}^{2}$ of 0.336 . This result indicates that Facebook users pay attention to the behavior of their relationships and the information posted on this specific social network is 
being observed and used as a source of information to guide the consumption intention of the users.

Including the mediation variables, the model displayed an $\mathrm{R}^{2}$ of 0.47 for the variable consumption intention, and this finding shows the representativeness of the model with regard to the impact of the perceived value, reputation and risk. One might suggest that, because these factors affect the consumption intention of network users, organizations interested in consumption should pay attention to those variables in addition to online recommendations posted in this social network.

At the moment of acquiring a product or service, consumers primarily make use of an intrinsic assessment of what they will acquire, and later choose based on a variety of existing extrinsic variables used to classify the product or service that which caught their attention. If a product or service is to be explicitly recommended, it must have some considerable value.

One of the most important values one builds in social networks is reputation, that is related to the information received by social actors regarding the behavior of others and the use of this information to decide how to behave. In every online community, reputation is a central component of connection and is often more valuable than money. One of the most important issues in the construction of social networks on the Internet is the fact that the platforms supporting them allow greater control of the impressions being voiced. Reputation is more easily built on the Internet by means of greater control over the impressions left by the actors.

The fact that the person voicing the opinion does not receive any material gain from the recommended action increases the probability of the advice being deemed credible, and this factor may also contribute to the building of a reputation. Reputation gains importance when it is difficult to assess the consumption experience prior to purchasing, as is usually the case when a service is purchased. However, Cai et al. (2014) finding that while reputation can facilitate trade through buyer experience and word-of-mouth, it is not as effective as centralized feedback.

Corroborating the results of Aarikka-Stenroos and Makkonen (2014), consumers look for information on a product or service through word of mouth communication when they attach a high risk level to the acquisition. This strategy is objective and logical: as the consumer gathers more information about the product, the consequences of the purchase become more predictable, and the perceived risk is therefore reduced. Appealing to a 
reference group can also help reduce the perceived risk in the consumption of a specific product or service.

An argument provided by an individual who endorses or gives a testimony may show the consumer that his doubts with regard to the product or service are unfounded. Through the Internet, every consumer has the possibility to interact with millions of other consumers, and consumers may use this interaction with other consumers as part of a strategy to reduce risk. These results are consistent with $\mathrm{Ha}$ (2012) added that word-of-mouth communication influence consumers more than do other types of information from online purchase.

If the influence on product and service consumption intention in the model proposed in this study displays significant impact, then marketing strategies of organizations interested in encouraging consumption should consider this issue when planning their strategies. This requires in-depth studies to identify how to develop actions that magnify these factors, e.g., the identification of the actors in the network with a higher reputation. Organizations may also use these comments to better understand the behavior of their clients and to improve their products adding more value to the customers. It is also important to note that, although it only has a slight impact on the model, the perceived risk factor is nonetheless significant. The low impact may be because intention was evaluated instead of real behavior. This relationship may be tested in future studies.

The Internet has changed the power structure in the sales world in favor of the buyer. Before Facebook, Twitter, and other social networking sites, salespersons were in charge of sales. With the advent of the Internet, consumers, armed with more knowledge than ever before, push the market forward. Through simple analysis of the content published on the web, these consumers have the power to make decisions based on praise, critique, half-truths, and lies about products and services. They use the Internet to get advantage and thus change the old game of relying just on information provided by the salespersons.

Salespersons may also benefit from this change introduced by the web. They may use the exchange of information on the products and services of their company or the competition to analyze the consumers' behavior and, as a result, to close deals faster. The challenge for organizations that attempt to adopt this strategy is the data management time due to the speed with which information circulates through the networks and the complexity of the phenomenon. 
Companies need to move at the speed of social networks, and sales professionals need to quickly identify, understand, and act on that information to make predictions on consumer behavior to grasp sales opportunities. Therefore, the data produced by the social network revolution also enable sales teams to be more efficient.

To act in this new context, companies need to develop the skills of their sales teams with regard to consumer behavior. They need to develop business analytics skills in order to be able to capture the information that circulates in the networks, organize and make sense out of the large amount of data available, and, from the analyses performed, outline sales strategies that meet the yearning of these wired consumers. Companies must balance the interactions between consumers and sales teams to make use of the opportunities that the knowledge of their consumers can bring. To accomplish this, the salespersons must be familiar with the tools required to collect and analyze these textual data and thus produce competitive intelligence from these analyzes in an adequate time period and thus keep pace with the social networks where this information is published.

Additionally, companies should note that sales are not the only point of contact between a company and its clients. Customer support and post-sales operations are also important links between the client and the organization. When a consumer shares information directly with the company, s/he may be supplying priceless clues to a puzzle that may, eventually, lead to a new sale. This intelligence gathered by the sales team and shared with the support teams must be used to predict the actions of prospective new clients.

After all, the present study contributes to the advancement of the theme of online recommendations (eWOM), particularly those recommendations that are communicated through social networking sites, such as Facebook, as well to the increase in the number of studies that include mediating variables in their study models.

Considering the limitations of this research, in future works, other aspects related to this study, including groups of different cultures, social classes, different segments, and product and service types, other social networks and qualitative approaches to better describe the phenomenon and causal mechanism regarding online recommendation and consumption intention might be also addressed. Previous studies show that the type of product affects the choices of the consumers who usually receive personal recommendations (BEARDEN; NETEMEYER; TEEL, 1982; CHILDERS; RAO, 1992; KING; BALASUBRAMANIAN, 1994). New constructs might also be included to increase the capacity to explain the factors that are involved in the consumption intention of these users, e.g., price factor and ease of 
access. In addition, the real behavior as a consequence of the consumption intention may also be assessed.

\section{CONTRIBUTIONS OF AUTHORS}

The article is the result of research developed as a requirement for completion of the Master Administration / UFES author Nelson Siqueira Rangel Netto under the guidance of Professor. Teresa Cristina Janes Carneiro and co-supervision of Prof. Marcos Paulo Valadares de Oliveira. Professor Rogério Antonio Monteiro was the author of the advisor

Nelson Siqueira Rangel Netto undergraduate and inspired the research that developed the master. It can guide you because not part of the faculty of the Graduate Diploma in Management UFES Program.

In the article, Teresa Cristina Janes Carneiro and Nelson Siqueira Rangel Netto developed the research model with the help of Prof. Rogerio Antonio Monteiro and defined the methodology with the participation of Prof. Marcos Paulo Valadares de Oliveira. Professor Marcos Paulo Valadares de Oliveira helped in the review of the theoretical model and the definition and implementation of the methodology. The authors were responsible for the analysis and discussion of the results of the research.

\section{REFERENCES}

AARIKKA-STENROOS L.; MAKKONEN H. S. Industrial buyers' use of references, wordof-mouth and reputation in complex buying situation. Journal of Business and Industrial Marketing, v. 29, n. 4, p. 344-352, 2014.

ARNDT, J. A. Role of product-related conversations in the diffusion of a new product. Journal of Marketing Research, v. 4, n. 3, p. 291-295, 1967.

BANSAL, H.S.; VOYER, P.A. word-of-mouth processes within a services purchase decision context. Journal of Service Research, v. 3, n. 2, p. 166-177, 2000.

BEARDEN, W; NETEMEYER, R. G.; TEEL, J. E. Measurement of consumer susceptibility to interpersonal influence. Journal of Consumer Research, v. 15, n. 4, p. 473-481, 1989.

BELK, R. W. Occurrence of word-of-mouth buyer behavior as a function of situation and advertising stimuli. In: AMERICAN MARKETING ASSOCIATION'S EDUCATORS CONFERENCE, 1971, Chicago, IL. Anais... Chicago: AMA, 1971. p. 419-422.

BERGER, J.; IYENGAR, R. Communication channels and word-of-mouth: how the medium shapes the message. Journal of Consumer Research, v. 40, p. 567-79, 2013.

BETTMAN, J. R. Perceived risk and its components: a model and empirical test. Journal of Marketing Research, v. 10, p. 184-190, 1973. 
BICKART, B.; SCHINDLER, R. Internet forums as influential sources of consumer information. Journal of Interactive Marketing, v. 15, n. 3, p. 31-40, 2001.

BONE, P. F. Determinants of word-of-mouth communications during product consumption. Advances in Consumer Research, v. 19, p. 579-583, 1992.

BROOKS, R.C. Word-of-mouth advertising in selling new products. Journal of Marketing, v. 22, p. 154-161, 1957.

BROWN, T. J. et al. Spreading the word: investigating antecedents of consumers' positive word-of-mouth intentions and behaviors in a retailing context. Journal of the Academy of Marketing Science, p. 123-138, 2005.

BUSKENS, V. The social structure of trust. Social Networks, v. 20, n. 3, p. 265-289, 1998.

BUTTLE, F. A. Word of mouth: understanding and managing referral marketing. Journal of Strategic Marketing, v. 6, p. 241-254, 1998.

CAI, H. et al. Seller reputation: from word-of-mouth to centralized feedback. International Journal of Industrial Organization, v. 34, n. 1, p. 51-65, 2014.

CANTALLOPS, A. S.; SALVI, F. New consumer behavior: a review of research on e-WOM and hotels. International Journal of Hospitality Management, v. 36, p. 41-51, 2014.

CHATTERJEE, P. Online reviews: do consumers use them? Advertising Consumer Research, v. 28, p. 129-133, 2001.

CHEN, P.T., HU, H.H. The effect of relational benefits on perceived value in relation to customer loyalty: an empirical study in the Australian coffee outlets industry. International Journal of Hospitality Management, v. 29, p. 405-412, 2010.

CHEUNG, C. M. K.; THADANI, D. R. The impact of electronic word-of-mouth communication: a literature analysis and integrative model. Decision Support Systems, v. 54, n. 1, p. 461-470, 2012.

CHEUNG, C. M. K; LEE, M. K. O; RABJONH, N. The impact of electronic word-of-mouth: the adoption of online opinions in online customer communities. Internet Research, vol.18, n.3. p.229-247, 2008.

CHU, S. C; KIM, Y. Determinants of consumer engagement in electronic word-of-mouth (e$W O M$ ) in social networking sites. International Journal of Advertising, v. 30, p. 47-75, 2011.

CUNNINGHAM, S. M. The major dimensions of perceived risk. In: COX, D.F. (Ed.). Risk taking and information handling in consumer behavior. Boston: Harvard University Press, p. 82-108, 1967.

DUANA, W.; BIN, G.; WHINSTON, A.B. The dynamics of online word-of-mouth and product sales: an empirical investigation of the movie industry. Journal of Retailing, v. 84, n. 2, p. 233-42, 2008. 
DUHAN, D.F. et al. Influences on consumer use of word-of-mouth recommendation sources. Journal of the Academy of Marketing Science, v. 25, n. 4, p. 283-295, 1997.

FEICK, L. F.; PRICE, L. L. The market maven: a diffuser of marketplace information. Journal of Marketing, v. 51, n. 1, p. 83-97, 1987.

FISHBEIN, M., AJZEN, I. Belief, attitude, intention, and behavior: an introduction to theory and research. Reading, MA: Addison-Wesley, 1975.

GODES, D.; MAYZLIN, D. Using online conversations to study word-of-mouth communication. Marketing Science, v. 23, p. 545-560, 2004.

GOLDENBERG, J; LIBAI, B; MULLER, E. Talk of the network: a complex systems look at the underlying process of word-of-mouth. Marketing Letters, v. 12, n. 3, p. 211-223, 2001.

GUPTA, P.; HARRIS, J. How e-WOM recommendations influence product consideration and quality of choice: a motivation to process information perspective. Journal of Business Research, v. 63, p. 1041-1049, 2010.

HA, H. Y. The effects of consumer risk perception on pre-purchase information in online auctions: brand, word-of-mouth, and customized information. Journal of ComputerMediated Communication, v. 8, n. 1, 2002.

HAIR JUNIOR., J. F. et al. Análise multivariada de dados. 6. ed. Porto Alegre: Bookman, 2009.

HAIR JUNIOR, J. F. et al. A primer on partial least squares structural equation modeling (PLS-SEM). California: Sage, 2014.

HARRISON-WALKER, L. J. The measurement of word-of-mouth communication and an investigation of service quality and customer commitment as potential antecedents. Journal of Service Research, v. 4, n. 1, p. 60-75, 2001.

HENNING-THURAU, T. et al. Electronic word of mouth via consumer-opinion platforms: what motivates consumers to articulate themselves on the internet? Journal of Interactive Marketing, v. 18, p. 38-52, 2004.

HONG, I. B.; CHO, H. The impact of consumer trust on attitudinal loyalty and purchase intentions in B2C e-marketplaces: intermediary trust vs. seller trust. International Journal of Information Management, v. 31, p. 469-479, 2011.

HUNG, K. H.; LI, S.Y. The influence of e-WOM on virtual consumer communities: social capital, consumer learning, and behavioral outcomes. Journal of Advertising Research, v.47 n.4, p.485-495, 2007.

HUNT, T. O poder das redes sociais. São Paulo: Gente, 2010.

IKEDA, A. A. A importância da comunicação informal na aquisição de bens e serviços. In: CORRÊA, T. G.; FREITAS, S. G. Comunicação, marketing, cultura: sentidos da administração, do trabalho e do consumo. São Paulo: Centro Lusitano de Cultura, 1999. p. 6779. 
KATZ, E.; LAZARSFELD, P. F. Personal influence: the part played by people in the flow of mass communications. Glencoe: Free Press, 1955.

KIM, S. H.; HOLLAND, S.; HAN, H. S. A structural model for examining how destination image, perceived value, and service quality affect destination loyalty: a case study of Orlando. International Journal of Tourism Research, v. 15, n. 4, p. 313-328, 2013.

KIM, S. E. The effect of service quality of medical tourism on perceived value, satisfaction, and word-of-mouth: chinese customers perspective. Health Service Management Review, v. 8, n. 1, p. 448-466, 2014.

KING, M. F. BALASUBRAMANIAN, S. The effects of expertise, end goal adoption and product type on preference formation strategy adoption. Journal of the Academy of Marketing Science, v. 22, p. 146-159, 1994.

KU, Y. C.; WEI, C. P.; HSIAO, H. W. To whom should I listen? Finding reputable reviewers in opinion-sharing communities. Decision Support Systems, v. 53, p. 534-542, 2012.

LEE, J.; PARK, D. H.; HAN, I. The effect of negative online consumer reviews on product attitude: an information processing view. Electronic Commerce Research and Applications, v. 7, p. 341-352, 2008.

LERRTHAITRAKUL, W.; PANJAKAJORNSAK, V. Channels of electronic word-of-mouth affecting consumers' buying decision-making process in the Low Cost Carriers (LCCs).

Research Journal of Business Management, v. 8, n. 4, p. 367-378, 2014.

LIN, C. H.; KUO, B. Z. L. Escalation of loyalty and the decreasing impact of perceived value and satisfaction over time. Journal of Electronic Commerce Research, v. 14, n. 4, p. 348$362,2013$.

LÓPEZ, M.; SICILIA, M. How WOM marketing contributes to new product adoption. European Journal of Marketing, v. 47, n. 7, p. 1089-1114, 2013.

MALHOTRA,N. K. Pesquisa de marketing: uma orientação aplicada. Porto Alegre: Bookman, 1999.

MORAN, G.; MUZELLEC, L.; NOLAN, E. Consumer moments of truth in the digital context: how search and e-word-of-mouth can fuel consumer decision-making. Journal of Advertising Research, v. 54, n. 2, p. 200-204, 2014.

PARK, D. H., LEE, J.; HAN, I. The effect of on-line consumer reviews on consumer purchasing intention: the moderating role of involvement. International Journal of Electronic Commerce, v. 11. n. 4, p. 125-148, 2007.

PROCTER, J.; RICHARDS, M. Word-of-mouth marketing: beyond pester power. Advertising \& Marketing to Children, v. 3, n. 3, 2002.

RAACKE, J.; RAACKE, J. B. MySpace and Facebook: applying the uses and gratifications theory to exploring friend-networking sites. Cyberpsychology \& Behavior, v. 11, n. 2, p. 169-174, 2008.

RECUERO, R. Redes sociais na internet. Porto Alegre: Sulina, 2009. 
REINGEN, P. H. A word-of-mouth network. Advances in Consumer Research, v. 14, p. 213-217, 1987.

RICHINS, M. L. Negative word-of-mouth by dissatisfied consumers: a pilot study. Journal of Marketing, v. 47, p. 68-78, 1983.

RICHINS, M. L.; ROOT-SHAFFER, T. The role of evolvement and opinion leadership in consumer word-of-mouth: an implicit model made explicit. Advances in Consumer Research, v. 15, p. 32-36, 1988.

SANCHEZ, R. F.; INIESTA, M. A. B. The concept of perceived value: a systematic review of the research. Marketing Theory, v. 7, p. 427-451, 2007.

SANDES, F. S.; URDAN, A. T. Electronic word-of-mouth impacts on consumer behavior: exploratory and experimental studies. Journal of International Consumer Marketing, v. 25, n. 3, p. 181-197, 2013.

SCHIFFMAN, L. G.; KANUK, L. L. Comportamento do consumidor. 6. ed. Rio de Janeiro: LTC, 2000.

SCHUBERT, P.; GINSBURG, M. Virtual communities of transaction: the role of personalization in electronic commerce. Electronic Markets, v. 10, n. 1, p. 45-55, 2000.

SENECAL, S.; NANTEL, J. The influence of online product recommendations on consumers' online choices. Journal of Retailing, v. 80, p. 159-169, 2004.

SHETH, J. N.; NEWMAN, B. I.; GROSS, B. L. Consumption values and market choices: theory and applications. Ohio: South Western Publishing, 1991.

SILVERMAN, G. How to harness the awesome power of word-of-mouth. Direct Marketing, p. 32-37, 1997.

SOLOMON, M. R. O comportamento do consumidor: comprando, possuindo e sendo. 5. ed. Porto Alegre: Bookman, 2002

SUN, J. How risky are services? An empirical investigation on the antecedents and consequences of perceived risk for hotel service. International Journal of Hospitality Management, v. 37, p. 171-179, 2014.

SUN, T. et al. Online word-of-mouth (or mouse): an exploration of its antecedents and consequences. Journal of Computer-Mediated Communication, v. 11, art. 11, 2006.

TAX, S. S.; BROWN, S. W.; CHANDRASHEKARAN, M. Customer evaluations of service complaint experiences: implications for relationship marketing. Journal of Marketing, v. 62, p. 60-76, 1998. 
VÁZQUEZ-CASIELLES, R.; SUÁREZ-ÁLVAREZ, L.; DEL RÍO-LANZA, A. B. The wordof-mouth dynamic: how positive (and negative) WOM drives purchase probability: an analysis of interpersonal and non-interpersonal factors. Journal of Advertising Research, v. 53, n. 1, p. 43-60, 2013.

WOOD, C. M.; SHEER, L. K. Incorporating perceived risk into models of consumer deal assessment and purchase intent. Advances in Consumer Research, v. 23, p. 399-404, 1996.

YANG, J. et al. The heterogeneous effect of WOM on product sales: why the effect of WOM valence is mixed? European Journal of Marketing, v. 46, n. 11, p. 1523-1538, 2012.

ZEITHAML, V. A. Consumer perceptions of price, quality, and value: a means-end model and synthesis of evidence. Journal of Marketing, v. 52, p. 2-22, jul. 1988.

ZHANG, K. Z. K. et al. Examining the influence of online reviews on consumers' decisionmaking: a heuristic-systematic model. Decision Support Systems, v. 67, p. 78-89, 2014.

\section{APPENDIX 1 - ELECTRONIC QUESTIONNAIRE}

\begin{tabular}{|l|l|l|}
\hline \multicolumn{2}{|l|}{$\begin{array}{l}\text { Online Recommendation } \\
\text { On Facebook, I ALSO... }\end{array}$} & References \\
\cline { 1 - 2 } Q1a & $\begin{array}{l}\text { Observe the preferences of my contacts regarding products and } \\
\text { services }\end{array}$ & $\begin{array}{l}\text { Sun et al. (2008), Chu and } \\
\text { Kim (2011), Cheung; Lee } \\
\text { and Rabjonh (2008) }\end{array}$ \\
\cline { 1 - 2 } Q1b & $\begin{array}{l}\text { Observe the experiences of my contacts regarding products and } \\
\text { services }\end{array}$ & $\begin{array}{l}\text { Receive direct recommendations from my contacts about } \\
\text { products and services }\end{array}$ \\
\cline { 1 - 2 } Q1c & $\begin{array}{l}\text { Request recommendations from my contacts about products and } \\
\text { services }\end{array}$ & \\
\hline Q1d & \multicolumn{1}{|l}{} \\
\hline
\end{tabular}

\begin{tabular}{|c|c|c|}
\hline \multicolumn{2}{|c|}{$\begin{array}{l}\text { Perceived Value of the Recommended Product } \\
\text { A RECOMMENDATION on Facebook made by my contacts has MORE } \\
\text { VALUE to me when it is related to products and services... }\end{array}$} & References \\
\hline Q2a & of quality & \multirow{9}{*}{$\begin{array}{l}\text { Adapted from Swenney et } \\
\text { al. (2001 - Perval scale), } \\
\text { Petrick (2002-Servperval } \\
\text { scale) }\end{array}$} \\
\hline Q2b & with consistent performance & \\
\hline Q2c & that make me feel good & \\
\hline Q2d & that give me pleasure & \\
\hline Q2e & that I can enjoy & \\
\hline Q2f & that help me feel accepted & \\
\hline Q2 g & that improve the way I'm perceived & \\
\hline Q2 h & that make a good impression of me on other people & \\
\hline Q2i & that are useful for me & \\
\hline
\end{tabular}




\begin{tabular}{|c|c|c|}
\hline \multicolumn{2}{|c|}{$\begin{array}{l}\text { Perceived Reputation of the Source of Information } \\
\text { A RECOMMENDATION of products and services on Facebook is MORE } \\
\text { VALUABLE to me when made by a... }\end{array}$} & References \\
\hline Q3a & trustworthy contact & \multirow{7}{*}{$\begin{array}{l}\text { Fombrum (1996), } \\
\text { Schiffman and Kanuk } \\
\text { (2010), Solomon (2002), } \\
\text { Petrick (2002 - Servperval } \\
\text { scale), Chen and Hu (2010) }\end{array}$} \\
\hline Q3b & contact who enjoys my credibility & \\
\hline Q3c & contact in whom I believe & \\
\hline Q3d & contact who I admire & \\
\hline Q3e & contact with a good reputation & \\
\hline Q3f & contact I deeply respect & \\
\hline Q3 g & contact with status & \\
\hline
\end{tabular}

\begin{tabular}{|c|c|c|}
\hline \multicolumn{2}{|c|}{$\begin{array}{l}\text { Perceived Risk in the Recommended Product } \\
\text { On Facebook, I give MORE VALUE to a RECOMMENDATION of products } \\
\text { and services when... }\end{array}$} & References \\
\hline Q4a & $\begin{array}{l}\text { I do not know the performance one should expect from these } \\
\text { products and services }\end{array}$ & \multirow{5}{*}{$\begin{array}{l}\text { Wood and Sheer (1996), } \\
\text { Swenney et al. (1999), } \\
\text { Schiffman and Kanuk } \\
\text { (2010), Ha (2002) }\end{array}$} \\
\hline Q4b & I do not know the reputation of these products and services & \\
\hline Q4c & $\begin{array}{l}\text { I do not know the possible physical damage that these products } \\
\text { and services may pose }\end{array}$ & \\
\hline Q4d & $\begin{array}{l}\text { I do not know the cost-benefit relationship of these products and } \\
\text { services }\end{array}$ & \\
\hline Q4e & $\begin{array}{l}\text { I do not have the time required to search for technical information } \\
\text { about these products and services }\end{array}$ & \\
\hline
\end{tabular}

\begin{tabular}{|l|l|l|}
\hline \multicolumn{2}{|l|}{$\begin{array}{l}\text { Consumption Intention } \\
\text { Regarding my consumption intention,... }\end{array}$} & \multirow{2}{*}{ References } \\
\cline { 1 - 2 } Q5a & $\begin{array}{l}\text { it is likely that I will consume a product or service recommended } \\
\text { by my contacts on Facebook }\end{array}$ & \multirow{2}{*}{ Fishbein and Ajzen (1975). } \\
\cline { 1 - 2 } Q5b & $\begin{array}{l}\text { I usually obtain the intention to consume a product or service } \\
\text { that my contacts recommended on Facebook }\end{array}$ & \\
\cline { 1 - 2 } Q5c & $\begin{array}{l}\text { I tend to consume products and services that my contacts on } \\
\text { Facebook say they like }\end{array}$ & $\begin{array}{l}\text { I tend to consume products and services that my contacts on } \\
\text { Facebook say they use }\end{array}$ \\
\cline { 1 - 2 } Q5d & &
\end{tabular}

